\title{
Do conservadorismo à tradição marxista: rumos políticos do Serviço Social na previdência
}

\section{Fernanda Mattos}

Universidade Estadual da Paraíba (UEPB)

\section{Do conservadorismo à tradição marxista: rumos políticos do Serviço Social na previdência}

Resumo: O presente artigo discute os influxos das matrizes de pensamento na legitimação, consolidação e profissionalização do Serviço Social na política previdenciária, com ênfase no conservadorismo e na tradição marxista. Busca apresentar os fundamentos do pensamento conservador, o modo como foram absorvidos na profissão, bem como a ruptura política indicada pela aproximação com a tradição marxista. Conclui, a partir de uma revisão bibliográfica, que o Serviço Social reinventa-se acompanhando os movimentos societários, associa-se a projetos políticos e tem papel ativo na consolidação dos mesmos.

Palavras-chave: Conservadorismo. Tradição marxista. Serviço Social Previdência social.

\section{From Conservatism to Marxist tradition: Political paths of social work in social security}

Abstract: This article discusses the influxes of the matrixes of thinking about the legitimation, consolidation and professionalization of social service in social security policy, with an emphasis on conservative thought and the Marxist tradition. It presents the foundations of conservative thinking, the way that it was absorbed by the profession, and the political rupture indicated by an approximation with the Marxist tradition. It concludes, based on a bibliographic review, that social service has been reinvented, accompanying social movements, while associating itself to political projects and has an active role in their consolidation.

Keywords: Conservatism. Marxist tradition. Social Service. Social Security. 


\section{Introdução}

A trajetória do Serviço Social no Brasil tem relação estreita com os movimentos societários engendrados na conjuntura política, econômica, social e cultural do país. A gênese, o processo de institucionalização, laicização, o movimento de reconceitualização e intenção de ruptura do Serviço Social com o conservadorismo não podem ser compreendidos sem uma leitura crítica dos momentos históricos do país.

Inserido em relações sociais contextualizadas na ordem do capital e como profissão inscrita na divisão sociotécnica do trabalho, as matrizes de pensamento assimiladas pelo Serviço Social nestes processos correspondem às visões de mundo relacionadas aos projetos societários. Assim, humanismo-cristão, positivismo e marxismo mantêm correlação intrínseca com a direção ético-política da profissão e essas vertentes teóricas têm, em cada momento histórico, incidências na escolha teórico-metodológica do Serviço Social, tanto na intervenção técnica como na direção ético-política de seu trabalho, proporcionando desdobramentos no cotidiano profissional.

O Serviço Social apresenta identificação singular com a Previdência, acompanhando os processos de continuidades e rupturas no tocante ao direcionamento das suas dimensões constitutivas na atualidade. Há mais de 70 anos fazendo parte da política previdenciária, o Serviço Social tem uma história de luta e de resistência diante dos embates enfrentados nessa área e nos debates internos da profissão, em que se destaca devido à capacidade de renovação e de legitimação da profissão.

O presente artigo busca compreender as expressões das matrizes de pensamento no processo de institucionalização e de legitimação da profissão na política previdenciária, desde o conservadorismo à tradição marxista. Para tanto, são discutidos, preliminarmente, aspectos do pensamento conservador com vistas a compreensão da vinculação ao pensamento burguês e ao positivismo. Trata-se de um processo histórico vinculado ao momento em que a burguesia ascende enquanto classe revolucionária e se transmuta em classe dominante. O objetivo desta discussão sobre o pensamento conservador é desmistificar a relação com o Serviço Social, muitas vezes limitada ao senso comum. Desse modo, serão apresentadas: a vinculação do projeto profissional, nas suas bases iniciais, ao projeto reformista-conservador alinhado ao processo de consolidação do capitalismo no Brasil; as tentativas de modernização e de ruptura; e a identificação aos interesses das classes trabalhadoras com a aproximação à tradição marxista.

O que se pretende analisar é como o processo de consolidação do Serviço Social está diretamente relacionado com as respectivas configurações assumidas a partir de cada vertente teórica evidenciando, assim, a relação da profissão com o contexto sócio-político e, consequentemente, com os desafios e limites impostos para a continuidade de sua legitimação.

\section{Serviço Social embebido no pensamento conservador}

A relação entre Serviço Social e o pensamento conservador pode ser reconhecida com a verificação de que as marcas do conservadorismo não são apenas escolhas políticas dos/as profissionais, mas referem ao projeto societário no qual está vinculado em um determinado momento histórico (SANTOS, 2007). Para evitar analogismos acríticos, é importante situar o pensamento conservador, e não naturalizar sua vinculação ao pensamento burguês ou ao positivismo. Quanto ao pensamento burguês, não há uma relação direta, pois, em sua origem, o pensamento conservador vincula-se aos estratos feudais que defendiam a retomada dos valores tradicionalistas do Antigo Regime contra as ideias progressistas da ordem burguesa no contexto de consolidação do capitalismo. Quanto ao positivismo, Löwy (1994), ao analisar a gênese histórica do pensamento positivista remontando a Saint-Simon, evidencia que as propostas deste pensador tiveram perspectiva subversiva, questionadora, pois ao discutir a sociedade como um corpo social, não o fez no sentido de garantir a continuidade do sistema vigente, mas em defesa do fim do absolutismo em nome das leis fisiológicas deste corpo social e de sua higiene.

Leila Netto (2011) assevera que o pensamento conservador é uma expressão cultural situada em um chão histórico, a saber, o tempo e o espaço da configuração da sociedade burguesa. No contexto da transição do feudalismo para a consolidação do capitalismo, da incitação provocada pela Revolução Industrial exigindo uma nova cultura para as relações sociais vigentes, têm-se os elementos que basearam a revolução burguesa. A mobilização política da burguesia, sua consolidação enquanto classe no novo modo de produção impôs modernizações às instituições sociais, mas "O protagonismo revolucionário da burguesia cede lugar a um desempenho defensivo, voltado para a manutenção das instituições sociais que criou” (NETTO, 2011, p. 47). Ao se afirmar como classe dominadora, a burguesia não mais defende ideais progressistas, uma nova ordem societária, mas busca composições culturais que fundamentem a manutenção de seu status quo. Neste giro, 
as propostas do capitalismo perderam seu caráter progressista, aquelas que entendiam a razão como ilimitado poder para conhecer o mundo e os processos sociais, passando, agora, a defender que à razão não cabe esse caráter de compreensão da totalidade social. Coutinho (2010) caracteriza esse giro como o momento da filosofia da decadência, justamente por romper com a tradição progressista. $\mathrm{O}$ autor ainda faz a relação deste momento à dissolução da filosofia de Hegel, o qual defende a compreensão da realidade a partir de um sistema de leis racionais, adotando categorias como humanismo, historicismo e razão dialética ${ }^{1}$. Assim, após a ascensão da burguesia como classe e como movimento do mesmo processo do surgimento do proletariado - e reconhecimento desta classe como classe para si - a burguesia torna-se classe conservadora voltada à justificação de sua legitimação. Nesse momento, "a razão é encarada com um ceticismo cada vez maior, ou renegada como instrumento do conhecimento, ou limitada a esferas progressivamente menores ou menos significativas da realidade" (COUTINHO, 2010, p. 22). Ou seja, a filosofia da decadência se materializará a partir do rompimento com os núcleos do pensamento hegeliano, substituídos pelo positivismo, individualismo e irracionalismo (COUTINHO, 2010).

José Netto (1994), afirma que a razão moderna e a lógica da ordem burguesa são colidentes com as implicações do historicismo e da dialética, pois estas tem como consequência a compreensão da condicionalidade histórica da ordem burguesa, de sua transitoriedade, o que pode detonar comportamentos políticos em busca de sua radical alteração. Mas a negação da razão como possibilidade de se apreender o real não significou o divórcio com a ciência, pelo contrário: "é assim que o conservadorismo vai dar as mãos ao positivismo e, no pós-48, fundando as modernas ciências sociais, tornar-se-á um importante componente da cultura burguesa do período da decadência" (NETTO, 2011, p. 52, grifos do autor).

Neste sentido, Löwy (1994) traz elementos que indicam Comte e Durkheim como os expoentes que embasarão teórica e ideologicamente o pensamento conservador. A partir de suas teorias serão justificadas as bases de legitimação da ordem vigente, naturalizando-as e tornando as relações sociais submetidas a leis invariáveis, autônomas à intervenção humana. Inclusive, Comte e Durkheim eram conscientes do caráter contrarrevolucionário de suas ideias no contexto de insurgências do movimento operário revolucionário. Comte emprega o positivismo como um método que pretende evitar as ameaças representadas pelas ideias críticas, anárquicas, subversivas do Iluminismo, tida como negativas. A partir dos princípios de Condorcet e Saint$\operatorname{Simon}^{2}$, fundamenta-se a rígida linearidade entre sociedade e natureza no que compete à sua interpretação e à vida social regida por leis sociais invariáveis. Percebe-se intrínseca a esta filosofia o princípio da resignação, pois, sendo as leis sociais invariáveis, cabe ao indivíduo aceitar a sua condição diante dos males inevitáveis. Durkheim, ao considerar os fatos sociais como coisas e a sociedade como um organismo social numa teoria funcionalista das classes sociais, são encimentadas questões ideológicas caras à ordem burguesa. Sob a perspectiva do caráter imutável das leis sociais, revoluções não são possíveis, desigualdades sociais são inevitáveis e conflitos entre as classes são ameaçadores à funcionalidade da sociedade. Segundo Löwy (1994, p. 29), o conservadorismo presente no método de Durkheim "permite legitimar constantemente, através de argumentos científico-naturais, a ordem (burguesa) estabelecida". Em síntese, estão delineados os pressupostos teóricopolíticos que demarcam o pensamento conservador presente na legitimação da sociabilidade burguesa e na construção do modo de produção capitalista.

O espraiamento destes ideais na consolidação do capitalismo no Brasil se concretizou ao ser assumida a direção política do projeto burguês, que se caracterizou como reformista-conservador. O Serviço Social nasce, neste contexto, embebido por tais fontes, com intervenção profissional pendente à manutenção da ordem vigente.

\section{O projeto reformista-conservador e o Serviço Social brasileiro: tradição marxista como possibilidade de ruptura}

A consolidação do capitalismo no Brasil se deu através da redefinição do papel do Estado e o fortalecimento da Igreja Católica. Segundo Ortiz (2010), este processo se engendrou arraigado às configurações particulares do país - colonialismo, escravismo - tendo como eixos principais a vertente laica conservadora, calcada no pensamento positivista; e a vertente confessional, expressa no humanismo-cristão. A autora, fundamentando a análise em teóricos destas vertentes, depreende que o raciocínio que baliza estas perspectivas compreende o Brasil "como um país onde a classe trabalhadora é absolutamente incapaz, a ordem deve ser pautada sob o binômio autoridade/obediência; e o Estado, ao lado da Igreja, deve ser suficientemente forte para conduzir o país e os brasileiros ao progresso" (ORTIZ, 2010, p. 101).

A cultura conservadora necessária para a modernização a ser empreendida no país enquanto exigência do capitalismo impôs a constituição de um projeto integrador, o reformista-conservador. Este é o contexto de inserção do Serviço Social brasileiro. 
A trajetória histórica do Serviço Social compreende momentos de continuidade e ruptura a partir de discussões, tanto no interior da profissão quanto com as condicionalidades históricas aos quais estava submetida. Nos idos do seu processo de institucionalização e laicização, a profissão teve uma transição da perspectiva humanista-cristã para a positivista e, posteriormente, aproximação com a tradição marxista. Sem pretender discutir a questão de forma reducionista, cabe um breve resgate deste processo, com atenção para os elementos incorporados das matrizes pelo Serviço Social.

Entre os teóricos do Serviço Social é consenso de que o surgimento da profissão se deu vinculada ao início do enfrentamento do Estado às expressões da questão social. No contexto de industrialização do país na era Vargas, tais expressões agudizaram-se, elevando novas lutas sociais tendo como protagonistas a classe trabalhadora. Sob influência da perspectiva humanista-cristã, tendo como referência os movimentos da Igreja Católica na busca de sua renovação sob discurso de militância contra as injustiças sociais, o Serviço Social se especializou como profissão de natureza técnica, porém de caráter confessional ${ }^{3}$.

A partir destes parâmetros, a atuação profissional se consolidava em defesa da justiça e da caridade, numa perspectiva reformadora, ao buscar a melhora da vida da classe trabalhadora dentro dos limites da ordem burguesa. Ivone Silva (2014) atenta para o fato de que na conjuntura proposta, as primeiras assistentes sociais tinham limitações conjunturais para atuar nas causas da questão social.

A profissionalização do Serviço Social teve influencia norte-americana a respeito dos procedimentos metodológicos. A partir dos anos 30 do século 20, não só foram criadas as primeiras escolas de Serviço Social no Brasil como também houve uma ampliação de espaços sócio ocupacionais através de políticas sociais implementadas pelo Estado, entidades filantrópicas e por empresas. Entretanto, a intervenção profissional nas expressões da questão social sob a influência do cristianismo e os interesses do Estado transmutados em demandas profissionais, não visualizavam esta como decorrência das contradições próprias do sistema de produção vigente, mas como uma questão moral e religiosa, de um lado, e questão de política e assistencialismo, por outro.

Segundo Iamamoto (2002), a atuação profissional

A trajetória histórica do

\section{Serviço Social compreende}

momentos de continuidade e

ruptura a partir de discussões,

tanto no interior da profissão

quanto com as

condicionalidades históricas

aos quais estava submetida. neste período caracteriza-se como de cunho doutrinário e moralizador ao ter como objetivo a reeducação da classe operária, enquadrando-a as necessidades de expansão do processo de produção. Neste sentido, menciona que o surgimento da profissão é embebido em ideias conservadoras. Ortiz (2010) é enfática ao afirmar a compatibilidade entre o Serviço Social, na sua gênese, e a ordem burguesa, uma vez que, chamado a executar políticas sociais, conseguiu dar respostas às expressões da questão social mediada pelo projeto reformista-conservador, donde vem a legitimidade para sua institucionalização. É importante não perder esta assertiva de vista, pois nos anos 60 do século 20 tem início o processo de renovação na profissão e, dado os movimentos realizados, caracteriza-se como uma renovação conservadora.

No contexto dos governos desenvolvimentistas, os/as assistentes sociais rediscutem a prática intervencionista do

Serviço Social tradicional, introduzindo, ainda alicerçado em valores humanistas, práticas pautadas no avanço técnico e ajustamento do indivíduo a uma sociedade harmônica. As contradições deste processo se avolumam durante a ditadura militar, período de recessão democrática e que, contraditoriamente, há um investimento em políticas sociais 4 . Segundo Ozanira Silva, (1994, p. 85), neste período, “a política social se coloca enquanto estratégia para atenuar as sequelas do desenvolvimento monopolista no país, marcado pela superexploração da força de trabalho e pela forte concentração de renda”. Tendo como fonte de legitimação da profissão as bases estatais, o Serviço Social, frente às exigências postas pelas novas formas de enfrentamento da questão social, busca avanço técnico e eficiência, em outros termos, busca sua modernização.

Há dois movimentos neste período que legitimam o caráter conservador na profissão: o primeiro é exógeno, diz respeito à erosão do tradicionalismo enquanto exigência da modernização do capitalismo frente a uma nova postura técnico-operativa para lidar com as expressões da questão social; e o segundo é endógeno, trata-se da compatibilidade do pensamento conservador às exigências ao mercado de trabalho do assistente social, a saber, a reprodução das relações capitalistas (SANTOS, 2007).

José Netto (2005) aponta três direções principais com o processo de erosão do Serviço Social alicerçado nas bases tradicionais no contexto de renovação da profissão: a perspectiva modernizadora no tocante às concepções profissionais; a reatualização do conservadorismo; e a intenção de ruptura. 
Cerceados pelo contexto repressor do governo ditatorial, a busca pela renovação no Serviço Social recai numa reatualização da herança conservadora. A profisssão não questionava as relações nas quais estava inserida e negava o caráter de classe na qual a sociedade estava estruturada, sendo o Movimento de Reconceituação direcionado ao investimento no aperfeiçoamento da técnica. A materialização do esforço da categoria neste movimento de renovação teórico-metodológica é a realização dos Encontros de Araxá (1967) e Teresópolis (1972). Segundo Ozanira Silva (1994, p. 88), "Os documentos produzidos, em ambos os encontros, explicitam e reafirmam a diretriz tradicional do Serviço Social que busca a integração social, assumindo a perspectiva de modernização colocada no contexto da sociedade brasileira como um todo".

A segunda direção, mencionada por José Netto (2005, p. 158), diz respeito à tendência de atuação do Serviço Social fundado na perspectiva de ajuda psicossocial, reclamando a doutrina fenomenológica. A reatualização do conservadorismo recusa o positivismo e os incipientes debates sobre a teoria marxiana no interior da profissão, e resgata o traço microscópico da profissão, pois "trata-se de uma 'cientificidade' evanescente, onde, em nome da 'compreensão', dissolvem-se quaisquer possibilidades de uma análise rigorosa e crítica das realidades macrossocietárias e, derivadamente, de intervenções profissionais que possam ser parametradas e avaliadas por critérios teóricos e sociais objetivos".

A terceira dimensão é um contraponto direto com as já explicitadas, uma vez que propõe a ruptura com o Serviço Social tradicional. Diz respeito à pretensão de romper com a tradição positivista e com a direção do reformismo conservador. Para tanto, recorre à tradição marxista, assumindo uma retórica politizada, ampliando as referências teóricas, políticas e ideológicas para se pensar a profissão.

A aproximação do Serviço Social com a teoria marxiana foi iniciada nos anos 60 do século 20, quando houve um travamento cultural com a conjuntura ditatorial ${ }^{5}$, com incidências para o amadurecimento teóricopolítico da profissão. Apesar de todos os equívocos advindos daí e suas consequências quando da reaproximação nos anos $70^{6}$, foram fomentadas as bases políticas para o amadurecimento nos anos 80 do século 20 , quando a teoria social de Marx é assumida como direção teórica da profissão, hegemonicamente.

Na conjuntura da abertura política e redemocratização do país, o Serviço Social enquanto profissão que surge fundamentada na vertente teórico-conservadora, baseada no positivismo, vê-se numa efervescência política e cultural, rediscutindo suas bases teórico-metodológicas e não só redefinindo, mas assumindo sua direção ético-política. A legitimidade profissional não é mais buscada na resposta aos objetivos institucionais, circunscritos nestes espaços, mas junto à classe trabalhadora.

É neste contexto que a perspectiva reformadora não responde mais aos interesses da profissão, a qual se reaproxima e amadurece frente às discussões em torno da teoria marxiana, desta vez com Marx. José Netto (1991) menciona, como resultados desta relação: a ampliação das temáticas discutidas no interior da profissão, tais como Estado, classes sociais, políticas e serviços sociais; a leitura crítica do lastro conservador na profissão, tanto nos aspectos teórico, quanto metodológicos; a necessidade de direção ético-política; e a referência ao caráter históricocrítico da profissão situado nas relações sociais inseridas nos movimentos da sociabilidade burguesa.

As contribuições da tradição marxista têm viabilizado investigações da realidade, elaborações teóricas e intervenções políticas da profissão diretamente comprometida com os interesses da classe trabalhadora. $\mathrm{O}$ discurso do direito tem se inserido no âmbito profissional, conforme lembra Gomes (2013), como um consenso, tornando-se imprescindível não superestimar a defesa dos direitos nos limites da ordem capitalista, tendo como expressão maior (e possível) a materialização de políticas sociais de caráter universal, uma vez que estas são incapazes de responder à cidadania plena e à emancipação da humanidade. E é justamente sob esta perspectiva que a matriz positivista não responde ao movimento atual da profissão que tem uma proposta revolucionária, derivada da teoria marxiana.

Cabe acrescentar que o capitalismo contemporâneo, sob o ordenamento do neoliberalismo, impõe a rearticulação do Serviço Social. Para além das questões objetivas que envolvem cortes de gastos sociais, reformas do Estado e focalização das políticas sociais (BEHRING, 2003), dentre outras, as questões subjetivas que perpassam a sociedade refletem diretamente no aporte teórico-metodológico da profissão e nas suas respostas aos diversos espaços sócio ocupacionais. As teorias sobre o fim da história, o apelo ao individualismo e a nova gestão da pobreza incidem sobre o fazer profissional. É neste sentido que a reafirmação categórica da perspectiva crítica-dialética novamente se faz urgente e necessária à profissão, no intuito de se evitar o discurso de que no estágio atual do capitalismo não há saídas e que as políticas sociais são o fim em si mesmo.

\section{Continuidades e rupturas no Serviço Social da Previdência}

Os movimentos engendrados na profissão no interior da política previdenciária estão conectados aos movimentos da conjuntura política e econômica, às configurações do Estado brasileiro, bem como, numa justa- 
posição, aos processos de continuidades e rupturas ocorridas no Serviço Social no país. Segundo Ademir Silva (2007, p. 26), "O Serviço Social previdenciário reproduz as ideias e as práticas de seu tempo histórico e não poderia ser diferente". Assumindo esta assertiva como premissa, será discutido como a profissão assimilou e/ ou questionou as matrizes de pensamento que incidiram na construção teórico-metodológica, técnico-operativa e ideo-política da profissão.

O contexto da gênese do Serviço Social na Previdência é situado na década de 40 do século 20, quando se propunha, no governo Vargas, a expansão das políticas sociais para amenizar as insatisfações sociais. Caracterizado como um Estado paternalista, a inserção do Serviço Social na estrutura previdenciária se deu no intuito de enquadramento e controle do proletariado. Em 1944, através das Portarias n. 25 e n. 52 do Conselho Nacional do Trabalho, houve a implementação do Serviço Social na Previdência e sua expansão nos Institutos de Aposentadorias e Pensões (IAPs) ${ }^{7}$.

A imagem da profissão, que legitimou suas respostas profissionais às demandas da política social, é a de que o Serviço Social garantiria a reconciliação dos usuários com a máquina administrativa. Sob o discurso da humanização, a intervenção profissional se daria no sentido de valorizar o homem enquanto pessoa humana e integrá-lo a sociedade. Iamamoto e Carvalho (2014), ao discutirem este momento histórico, enfatizam que os objetivos institucionais eram assimilados aos objetivos profissionais, uma vez que a atuação se concretizava na seguinte direção: ação fiscalizatória, moralizadora, integração dos usuários à política previdenciária; ajustamento dos indivíduos a ordem com prevenção e intervenção de conflitos; individualização das demandas, dentre outros aspectos. Tais elementos são alinhados com uma perspectiva conservadora, pois, ao se intervir numa perspectiva fiscalizatória e moralizadora, trabalha-se uma consciência voltada para o trabalho subordinado ao capital, nos aspectos pertinentes a não perturbação de sua reprodução e ampliação. Quando se discute o ajustamento de indivíduos, a prática volta-se para a neutralização dos inconformismos e possíveis mobilizações reivindicatórias por parte da classe trabalhadora e a individualização das demandas desvincula os indivíduos de seu caráter de classe, mistificando o contexto socioeconômico no qual está inserido ao desvinculá-lo das relações sociais de produção. Ao responder as demandas institucionais, o Serviço Social garantiu sua institucionalização, fazendo-se imprescindível ao alcance dos objetivos institucionais, uma vez que a ação ideológica inserida na prática profissional "tem por efeito constituir-se no elemento principal de amortecimento de contradições que se manifestam dentro do âmbito das relações sociais englobadas na própria instituição e, como elemento auxiliar, contribuir para a eficiência no desempenho da instituição em sua função de enquadramento político e controle social" (IAMAMOTO; CARVALHO, 2014, p. 323).

Esta foi à direção teórico-metodológica assumida pelo Serviço Social na política previdenciária consolidada nos anos $70^{8}$ do século 20, quando se inicia a discussão sobre o Movimento de Reconceituação no âmbito da profissão. Inserido no período ditatorial e na modernização conservadora ensaiada na política brasileira, o Serviço Social neste espaço sócio ocupacional é influenciado, mediante as exigências de modernização burocrática. O projeto de modernização é expresso na política previdenciária através dos Planos Básicos de Ação de 1972 e 1978.

O primeiro Plano Básico de Ação (PBA) ratifica a perspectiva da profissão nas bases do desenvolvimento sob o viés de práticas conservadoras, respondendo assim à racionalidade técnica administrativa do governo ditatorial. Ao rediscutir sua intervenção profissional no âmbito previdenciário, estimulada pela modernização da estrutura do governo, é enfatizada a padronização e operacionalidade técnica em detrimento de uma análise macrossocietária. Os desdobramentos para a intervenção profissional são diversos: ação políticoideológica individualizante e com orientação psicossocial; questão social entendida enquanto problemas individuais dos sujeitos; negligenciamento dos aspectos macrossocietários na leitura da realidade; e reivindicações dos usuários como problemas a serem corrigidos. Abreu e Lopes (2007, p. 60) compreendem que o projeto profissional, neste momento histórico, "reatualiza princípios tradicionais da individualização e da autodeterminação do sujeito atendido pelos serviços previdenciários, que tendem a pulverização dos atendimentos às demandas sociais e legitimar a ênfase no esforço individual na busca de respostas solitárias a suas necessidades imediatas e mediatas".

As exigências administrativas, tendo como parâmetro o alinhamento entre os interesses do capital (reprodução e expansão), do Estado e da profissão, já no terreno de disputa pela redemocratização no país, resultam em um novo documento para cimentar bases técnico-científicas da profissão, a saber, o PBA de 1978. O Serviço Social passa a atuar junto às áreas de previdência, saúde e assistência e com maior interlocução nas esferas de atuação. Porém, o processo de renovação, a despeito das discussões críticas que vinham acontecendo na América Latina e em outros espaços no Brasil ${ }^{9}$, bem como da consciência de se reconhecer polarizado frente os interesses que o cerceiam e o demandam, retoma o caráter funcionalista e de apaziguador de conflitos. Considera-se que o PBA de 1978 reatualizou o papel do Serviço Social como integrador do segurado à política previdenciária, caracterizando o processo de modernização ainda incipiente nos seus processos de ruptura com o Serviço Social tradicional (CARTAXO, 2008). 
É perceptível que desde o seu surgimento até meados dos anos 70 e 80 do século 20, a profissão no âmbito da previdência é embebida por práticas e justificações teóricas conservadoras, calcadas no positivismo. Com vistas à legitimação da ordem vigente, não são reconhecidos o status quo ou as correlações de forças enquanto inerentes às contradições societárias da sociabilidade capitalista. Apenas a partir dos anos 80 do século 20, concomitante às discussões a nível nacional, são postas outras bases de legitimidade da profissão. $\mathrm{O}$ documento catalisador desta nova perspectiva que materializa a intenção de ruptura com as bases tradicionais da profissão, é a Matriz Teórico-Metodológica do Serviço Social (1994), a qual traz instrumentos e técnicas, princípios e diretrizes para subsidiar a intervenção profissional.

No contexto da garantia da Previdência Social enquanto política integrante do sistema de proteção social brasileiro e, concomitantemente, do tensionamento para sua efetivação com a ofensiva neoliberal assumida pelos governos que se seguiram na década de 90 do século 20, o Serviço Social assumiu a defesa da democracia e a da Previdência de "caráter público, de real universalidade, descentralizado, democrático, redistributivo, que garanta a manutenção digna do trabalhador e de sua família, sob o controle dos usuários", conforme explicitado na Matriz (MPAS, 1994). O contexto econômico e político na época da publicação deste documento representava o auge do reordenamento das políticas sociais sob o prisma neoliberal, processo pelo qual a Previdência não passou imune. As reformas gerenciais tiveram rebatimento direto no Serviço Social, desde ameaças a exclusão no organograma do Instituto Nacional de Seguro Social (INSS), até sua reestruturação dentro do órgão.

A aproximação da profissão com o método crítico-dialético, viabilizado com a Matriz, possibilitou um novo fôlego ao pensar e ao agir profissional o qual passou a trabalhar no refluxo das orientações da política nacional. As implicações da adoção deste método, grosso modo, são: perceber e discutir o exercício profissional a partir da realidade, apreensão da realidade com vistas à sua transformação, posicionamento em defesa dos direitos dos usuários, consideração das relações sociais de produção e da correlação de forças sociais na condução da história. À implementação da Matriz, conforme análise de Moreira (2008), faltaram condições objetivas para sua concretização. Há vinte anos referendada enquanto direção política da profissão no instituto ${ }^{10}$, isto não implicou na eliminação dos aspectos conservadores na intervenção profissional. O processo de implantação ainda está em disputa com práticas baseadas no pensamento conservador, de caráter funcionalista.

Após a implantação da Matriz houve modificações diversas no âmbito previdenciário, por exemplo: novas atribuições privativas, ampliação do quadro de profissionais, ataques à previdência pública através de reformas, reconfiguração do mercado de trabalho com o aprofundamento do desemprego crônico. São questões que têm incidências no exercício profissional e que exigem a consolidação das propostas da Matriz a qual tem como pressuposto o amadurecimento político dos/as profissionais nas dimensões constitutivas da profissão.

\section{Considerações finais: o que esperar da história?}

A legitimação, consolidação e amadurecimento da profissão são perpassados por determinantes históricos vinculados ao contexto macroestrutural de resposta do Estado às expressões da questão social, sob a ótica de garantia das condições de reprodução do capital.

Sem deslocar o chão onde a profissão se situa, ou seja, as relações sociais capitalistas, quando se discute as matrizes de pensamento assimiladas pelo Serviço Social nestes processos evidenciam-se o forte caráter conservador, o qual o perpassa da sua gênese até a contemporaneidade. No seu contraponto, possível através da aproximação com a tradição marxista e ao amadurecimento teórico-metodológico e ético-político a partir desta vertente, as disputas são cotidianas para o estabelecimento de uma cultura profissional legitimadora do método crítico-dialético, devido a forte presença do viés positivista nas suas dimensões.

Na política previdenciária, a profissão não está imune às incidências deste aspecto conjuntural, mas é sujeito desta movimentação de continuidades e rupturas. A partir das discussões pontuadas nesse artigo, são evidenciados os influxos das matrizes de pensamentos no seu processo de legitimação, consolidação e profissionalização na referida política. Destarte, durante sua trajetória de 70 anos na Previdência, o Serviço Social mudou radicalmente seu centro de atuação e compreensão da realidade. No primeiro momento, negava as relações de classe, buscava atuação no sentido de conter indignações, integrar e ajustar os usuários conforme desejos da política, legitimando assim o sistema vigente. Com o amadurecimento da profissão, a aproximação tanto com os movimentos sociais quanto com a teoria marxiana, passou a compreender a realidade a partir dela mesma, não negando as contradições inerentes à sociedade capitalista, atuando na defesa da política previdenciária pública e em defesa dos direitos dos usuários, conforme princípios e objetivos contidos na Matriz Teórico-Metodológica do Serviço Social no INSS.

A influência da teoria marxiana, com o seu viés revolucionário, impulsionou a profissão a discutir a política social, inclusive a previdenciária, para além dos aspectos burocráticos, ao inseri-la na dinâmica de avidez do 
capital por valorização e expansão. Na realidade contemporânea em que a política (não só) serve aos interesses de mercado, é um grande desafio à categoria não se prender naquelas análises que compreendem a realidade como muito complexa e diversificada, portanto, impossível de se conhecer e intervir. Depreende-se que, assim como não é possível creditar um fim à história, ao Serviço Social não é possível afirmar que as suas configurações atuais são sólidas e impassíveis à mudança, pois a realidade atual não é só mutável como também acompanha os movimentos da história. Num contexto de transformações societárias, cabe o alerta de permanecer firme na defesa do que foi conquistado até aqui, tanto no que se refere à política quanto ao amadurecimento teóricometodológico, técnico-operativo e ético-político, sem deixar de vislumbrar a urgência em se avançar em direção à universalização e no fortalecimento da profissão, legitimada a partir dos interesses das classes subalternas.

\section{Referências}

ABREU, M. M.; LOPES, J. B. O Plano Básico de Ação do Serviço Social no INPS - 1972: racionalidade técnica modernizadora no serviço assistencial da política previdenciária. In: Serviço Social na Previdência: trajetória, projetos profissionais e saberes. BRAGA, Léa; CABRAL, Maria do Socorro Reis (Orgs.). São Paulo: Cortez, 2007.

BEHRING, E. Brasil em contrarreforma: desestruturação do Estado e perda de direitos. São Paulo: Cortez, 2003.

CARTAXO, A. M. B. Estratégias de sobrevivência: a previdência e o serviço social. São Paulo: Cortez, 2008.

COUTINHO, C. N. O estruturalismo e a miséria da razão. São Paulo: Expressão Popular, 2010.

GOMES, C. Em busca do Consenso: radicalidade democrática e afirmação de Direitos. Tendências contemporâneas no Serviço Social. Rio de Janeiro: Lumen Juris, 2013.

IAMAMOTO, M. V. Renovação e conservadorismo no Serviço Social. São Paulo: Cortez, 2002.

IAMAMOTO, M.; CARVALHO, R. de. Relações Sociais e Serviço Social no Brasil: esboço de uma interpretação histórico-metodológica. 40. ed. São Paulo: Cortez, 2014.

LÖWY, M. As aventuras de Karl Marx contra o Barão de Munchahüssen. Marxismo e positivismo na Sociologia do Conhecimento. São Paulo: Busca Vida, 1987.

MOREIRA, M. C. O Serviço Social do INSS a partir da década de 1990: análise da implantação da Matriz Teórico-Metodológica. In: BEHRING, E. R.; ALMEIDA, Maria Helena Tenório de. (Orgs.). Trabalho e seguridade social: percursos e dilemas. São Paulo: Cortez: Rio de Janeiro, 2008.

MINISTÉRIO DA PREVIDENCIA E ASSISTENCIA SOCIAL. Matriz Teórico-Metodológica do Serviço Social do INSS. Brasília: MPAS, 1995.

NETTO, L. E. O conservadorismo clássico: elementos de caracterização e crítica. São Paulo: Cortez, 2011.

NETTO, J. P. Notas sobre marxismo e Serviço Social, suas relações no Brasil e questão de ensino. In: Cadernos ABESS. N. 4. Cortez: São Paulo, 1991.

. Razão, ontologia e práxis. In: Serviço Social e Sociedade, n. 44, ano XV. São Paulo, 1994.

Ditadura e Serviço Social: uma análise do serviço social no pós-64. São Paulo: Cortez, 2005.

ORTIZ, F. G. O Serviço Social no Brasil: os fundamentos de sua imagem social e autoimagem de seus agentes. Rio de Janeiro: E-papers, 2010.

SANTOS, J. S. Neoconservadorismo pós-moderno e Serviço Social Brasileiro. São Paulo: Cortez, 2007.

SILVA, A. A. da. O Serviço Social na Previdência Social: entre a necessidade social e o benefício In: Serviço Social na Previdência: trajetória, projetos profissionais e saberes. BRAGA, Léa; CABRAL, Maria do Socorro Reis (Orgs.). São Paulo: Cortez, 2007.

SILVA, I. M. F. da. Questão Social e Serviço Social no Brasil: fundamentos sócio históricos. São Paulo: Papel Social, 2014.

SILVA, O. S. O Serviço Social na conjuntura brasileira: demandas e respostas. Serviço Social e Sociedade, nº 44, ano XV. São Paulo, 1994.

\section{Notas}

1 Coutinho (2010) enfatiza que a racionalidade concretizada em Hegel é idealista, mas é indiscutível a contribuição para a tradição progressista na compreensão do real com a estruturação dos três núcleos do pensamento burguês revolucionário: humanismo - homem produto de sua própria atividade-, historicismo concreto - caráter histórico da realidade-, e a razão dialética-racionalidade objetiva conectada ao desenvolvimento da realidade e apreensão do real que supera o saber imediato.

2 Positivismo moderno é descendente da filosofia do Iluminismo, sendo Condorcete Saint-Simon pensadores da gênese histórica desta corrente de pensamento. Condorcet defende que os fenômenos sociais estão submetidos às leis necessárias e constantes e que as ciências da sociedade devem ser livres de paixões e interesses, a exemplo das ciências naturais. Saint-Simon afirma que qualquer fenômeno pode ser observado do ponto de vista da fisiologia e que a ciência política positiva deverá ser neutra e objetiva (LÖWY, 1994).

3 Ivone Silva (2014) remete ao depoimento de Helena Iracy Junqueira, uma das primeiras assistentes sociais diplomadas no Brasil, em 1938, a qual afirma que a visão de mundo era baseada na visão social da Igreja. 
4 Ozanira Silva (1994,p. 87), explana sobre a incidência que as configurações da política social assumidas no período ditatorial tem na profissão: "A política social, assumida pela complexidade desse conjunto de entidades e programas, passa a contar com o assistente social como categoria profissional intensamente responsável pela sua operacionalização, o que, inevitavelmente, faz com que a profissão seja influenciada pelas características marcantes da política social, nesse período, quais sejam: centralização e consequente burocratização, socialização dos custos e privatização dos setores mais rentáveis".

5 A discussão com a teoria marxiana no Brasil foi inserida nos anos 1950, diretamente circunscrita ao âmbito partidário, vinculada à elaboração teórica, política e ideológica do Partido Comunista Brasileiro, PCB. Na transição para os anos 1960, gradativamente se espraia para além dos muros partidários, inspirando pensadores e intelectuais sem vinculação com o referido partido. José Netto (2005) menciona que, com o processo ditatorial, houve uma liquidação sociopolítica deste processo, mas não abortou esta aproximação, considerando-a como a base para a constituição de uma tradição marxista no país.

6 As primeiras aproximações do Serviço Social com a tradição marxista foram alvo de críticas de muitos teóricos dentro do Serviço Social, a exemplo de Consuelo Quiroga. Em seu livro Invasão positivista no marxismo: manifestações no ensino da metodologia no Serviço Social, publicado pela Cortez em 1991, a autora faz uma incursão sobre o significado da invasão oculta do positivismo nas esferas da vida social e, inclusive, na tradição marxista, assimilada e reproduzida no Serviço Social na disciplina de Metodologia.

7 Neste contexto, a Previdência Social passa a ter importância na burocracia estatal no sentido de partícipe do arcabouço legal-institucional de regulação das relações de trabalho (Silva, 2007).

8 Nos anos 1960, a Lei Orgânica da Previdência Social é instituída, reiterando o caráter de prevenção e correção de ajustamentos no tocante à intervenção técnica do Serviço Social.

9 No Serviço Social da Previdência a situação de polarização inseriu a discussão sobre a possibilidade do atendimento no cotidiano profissional atuar na direção de instrumentalizar o segurado e não apenas passar por uma orientação técnica burocrática (CARTAXO, 2008). Neste período, as tendências críticas ao Serviço Social tradicional são evidenciadas, conforme discussões concretizadas no III Congresso Brasileiro de Assistentes Sociais, conhecido como o Congresso da Virada.

10 Desde então não houve redirecionamento político ou documento que o confrontasse, mas sim orientações técnicas que o referendam. O Manual Técnico do Serviço Social emitido através da Resolução INSS/PRES Nº 203, DE29 DEMAIO DE 2012, traz direção a respeito das linhas de ação, instrumentos e técnicas utilizadas no cotidiano profissional. Uma das atuais demandas prementes da categoria é a divulgação das atribuições do/ a assistente social no INSS que se encontra, desde 2007, aguardando aprovação do Ministério de Planejamento, Orçamento e Gestão.

\section{Fernanda Mattos}

fernandagmattos@gmail.com

Mestranda do Programa de Pós-Graduação em Serviço Social na Universidade Estadual da Paraíba (UEPB)

Assistente Social no Instituto Nacional do Seguro Social em Campina Grande, PB.

\section{Instituto Nacional do Seguro Social}

Av. Vigário Calixto, 418, Catolé

Campina Grande - Paraíba - Brasil

CEP: $58410-3400$ 